\title{
Aplikasi Interaksi Manusia Komputer Pada Pemodelan Sistem Informasi Perparkiran Gedung Bertingkat
}

\author{
Alit Swamardika, I.B ${ }^{1}$., Ida Ayu Sri Adnyani ${ }^{2}$ \\ ${ }^{1}$ Teknik Elektro Fakultas Teknik Universitas Udayana \\ ${ }^{2}$ Teknik Elektro Universitas matarama \\ gusalit@unud.ac.id ${ }^{1}$, adnyani70@yahoo.co.id ${ }^{2}$ \\ doi: https://doi.org/10.24843/JEI.2019.v05.i01.p05
}

Article Received: 15 Januari 2019; Accepted: 20 Mei 2019; Published: 30 Juni 2019

\begin{abstract}
Abstrak
Perkembangan kepemilikan kendaraan pribadi sangat pesat, namun tidak diimbangi oleh infrastruktur penunjang yang memadai seperti jalan dan lahan parkir. Khususnya untuk lahan parkir, parkir secara horisontal akan susah dikembangkan karena terbatasnya ketersediaan lahan, sehingga penambahan lahan parkir dapat dilakukan secara vertikal yaitu dengan membuat gedung parkir bertingkat. Selama ini keberadaan gedung parkir bertingkat belum menyediakan sistem informasi kondisi tersedia atau tidaknya tempat parkir. Bentuk lahan parkir yang bertingkat sering kali membuat pengemudi harus berputar-putar untuk mencari tempat yang kosong, hal ini mengakibatkan pemborosan energi dan waktu. Penelitian ini bertujuan untuk mendesain sistem informasi lokasi ruang parkir kosong atau sudah terisi, sehingga dapat mempercepat waktu dan mempermudah pengemudi dalam mencari tempat parkir untuk memarkir mobilnya sebagai model aplikasi dalam interaksi manusia komputer. Desain prototype sistem informasi ini terdiri dari tiga bagian utama yaitu sensor, kontroler, dan display. Sistem kontrol parkir mobil yang bekerja dengan portal otomatis (parking gate) disertai layar display untuk informasi lokasi ruang parkir yang kosong maupun yang sudah terisi. Portal akan terbuka jika informasi menyatakan tempat parkir masih tersedia, dan portal tidak akan terbuka jika informasi menyatakan parkir sudah penuh.
\end{abstract}

Kata kunci: gedung bertingkat, parkir, pemodelan sistem, sistem informasi, interaksi manusia komputer

\section{Application Of Computer Human Interaction In Modeling Parking Information Systems In Multi-Storey Buildings}

\begin{abstract}
The development of private vehicle ownership is very rapid, but it is not balanced by adequate supporting infrastructure such as roads and parking lots. Especially for parking lots, parking horizontally will be difficult to develop because of the limited land availability. The addition of parking lots can be done vertically by building a multi-storey parking building. So far, the existence of multi-storey parking buildings has not provided an information system on the availability of parking spaces. The form of multi-storey parking lots often makes the driver have to go around few times to find an empty space. This situations wasting of energy and time. This study aims to design an information system as application models in human-computer interaction, that will inform someone there is empty or already filled parking space, so that it can save time and make it easier for drivers to find parking spaces to park their cars. This information system prototype design consists of three main parts, called sensors, controllers, and displays. Car parking control system that works with an automatic portal (parking gate) along with a display screen for information on the location of empty
\end{abstract}


parking spaces and those that have been filled. The portal will open if information states the parking lot is still available, and the portal will not open if information states the parking lot is full.

Keywords: multi-storey building, parking, system modeling, information systems, human computer interaction

\section{PENDAHULUAN}

Perkembangan kepemilikan kendaraan pribadi sangat pesat, namun tidak diimbangi oleh infrastruktur penunjang yang memadai seperti jalan dan lahan parkir. Khususnya untuk lahan parkir, parkir secara horisontal akan susah dikembangkan karena terbatasnya ketersediaan lahan, sehingga penambahan lahan parkir dapat dilakukan secara vertikal yaitu dengan membuat gedung parkir bertingkat. Bentuk lahan parkir yang bertingkat sering kali membuat pengemudi harus berputar-putar untuk mencari tempat yang kosong, hal ini mengakibatkan banyak waktu terbuang dan kadang cukup merepotkan hanya untuk mencari tempat parkir pada jam sibuk, sehingga pengemudi lebih cenderung memarkir kendaraannya di pinggir jalan dan mengakibatkan kemacetan lalu lintas di jalan raya (Setiawan, 2007).

Selama ini keberadaan gedung parkir bertingkat belum menyediakan sistem informasi kondisi tersedia atau tidaknya tempat parkir khususnya di portal masuk, sehingga pengemudi tidak mengetahui kondisi parkir di dalam gedung. Penelitian sistem parkir otomatis sudah banyak dilakukan, seperti Pambudi (2007), Winarsih dan Mahendra (2009), maupun Purwanto (2011), namun belum ada yang membahas ketersediaan informasi kondisi parkir di portal masuk. Dalam bidang ergonomi, kajian ergonomi dibedakan menjadi empat kelompok, salah satunya adalah kajian interaksi manusia komputer khususnya lagi tentang tampilan/display yakni kajian pada suatu perangkat (interface) yang menyajikan informasi tentang lingkungan dan mengkomunikasikannya pada manusia antara lain dalam bentuk tanda-tanda, angka, dan lambang (Wardani, 2003).

Salah satu solusi untuk menanggulangi permasalahan parkir adalah dengan mendesain sistem informasi penunjuk lokasi ruang parkir kosong dan yang sudah terisi di portal masuk gedung sehingga dapat mempercepat waktu dan mempermudah pengemudi dalam mencari tempat parkir untuk memarkir mobilnya. Apabila tempat parkir sudah terisi semua maka display akan menampilkan informasi bahwa tempat parkir penuh dan portal (parking gate) tidak akan terbuka, sehingga pengemudi dapat mencari tempat parkir lain di luar gedung dan mengurangi waktu terbuang sia-sia hanya untuk berputar di gedung bertingkat yang parkirnya sudah penuh. Hal ini sesuai dengan kegunaan penerapan ergonomi dalam interaksi manusia mesin, dimana mengaplikasikan aspek-aspek ergonomi dengan memanfaatkan informasi mengenai sifat, kemampuan dan keterbatasan manusia dapat dirancang sebuah stasiun kerja yang bisa dioperasikan dengan baik. Dalam arti dapat mencapai tujuan yang diinginkan melalui aktivitas tersebut dengan efektif, efisien, aman dan nyaman.

\section{METODE}

Desain prototype sistem informasi lokasi parkir mobil terdiri dari tiga bagian utama yaitu sensor, kontroler, dan display. Sensor yang digunakan adalah infra red dan photo dioda yang diletakkan pada portal (parking gate) masuk yang digunakan untuk mendeteksi awal kedatangan mobil dan setiap blok ruangan parkir yang digunakan untuk mendeteksi ada tidaknya mobil pada setiap blok ruangan parkir. Mikrokontroler ATMega16 digunakan untuk memproses data. Display digunakan untuk menunjukkan informasi lokasi blok ruangan parkir yang berisi atau kosong. Proses informasi sejak masukan sampai menjadi informasi dalma 
bentuk tampilan dikaji secara naratif. Analisis terhadap perangkat yang digunakan dalam mendesain system informasi parker disajikan dalam bentuk gambar dan narasi.

\section{HASIL DAN PEMBAHASAN}

Metode perancangan sistem kontrol ini terdiri atas perancangan perangkat keras dan perancangan perangkat lunak. Skema perancangan perangkat lunak menggunakan alur pemikiran yang disusun dalam bentuk algoritma untuk menyelesaikan suatu masukan mobil parkir dan menghasilkan informasi dalam bentuk display. Tayangan yang ditampilan dalam layar menunjukkan ada tidaknya parker kosong dan sekaligua terkait dengan system buka tutup portal secara ototmatis. Algoritma dari system informasi yang diterapkan menggunakan diagram alir seperti Gambar 1.

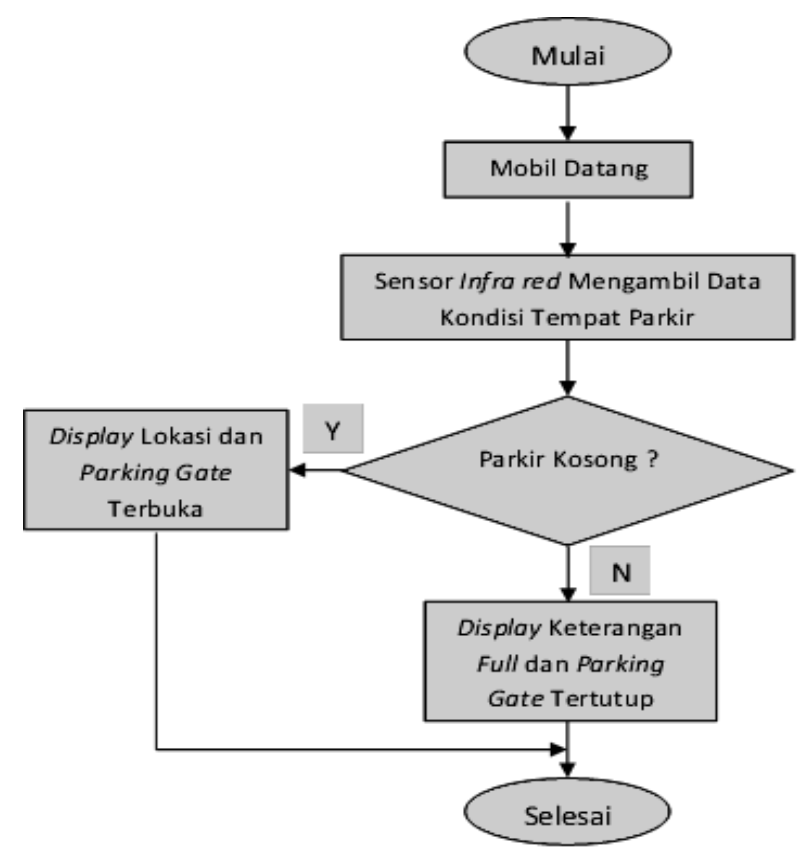

Gambar 1. Flowchart Sistem Informasi Parkir (Trikrisna dkk., 2013)

Perancangan perangkat keras meliputi bagian input yang terdiri dari rangkaian sensor infrared dan photo transistor sebagai pendeteksi kedatangan mobil sebelum masuk areal parkir dan keberadaan mobil pada masing-masing kotak ruangan parkir (Gambar 2).

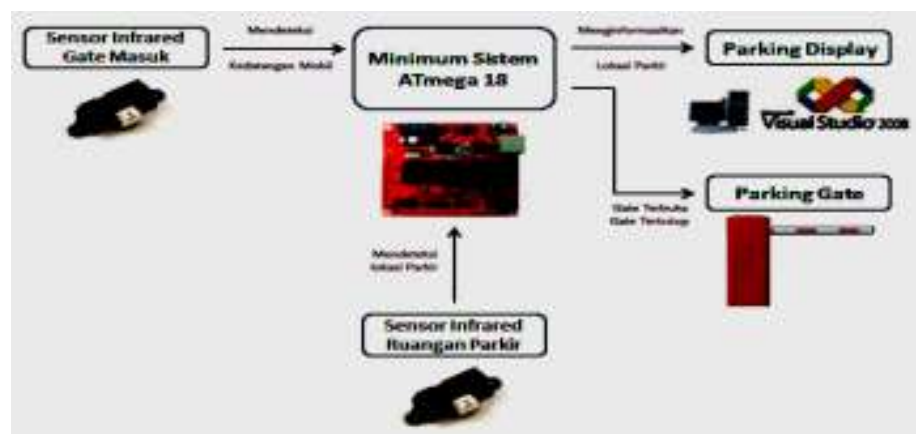

Gambar 2. Blok Diagram Pemodelan Sistem Parkir (Trikrisna dkk., 2013)

Bagian kontrol terdiri dari rangkaian minimum sistem mikrokontroler AVR ATmega16 yang bekerja mengatur keseluruhan dari pada sistem ini. Bagian output terdiri dari display 
layar monitor guna menampilkan informasi letak ruang parkir yang kosong maupun yang sudah terisi dan portal (parking gate) sebagai gerbang sebelum memasuki areal parkir yang akan terbuka bila masih ada ruangan parkir yang kosong dan tetap tertutup bila sudah semua terisi.

Hasil perancangan prototype parkir dan penempatan kode dari masing-masing ruangan tampak seperti Gambar 3.

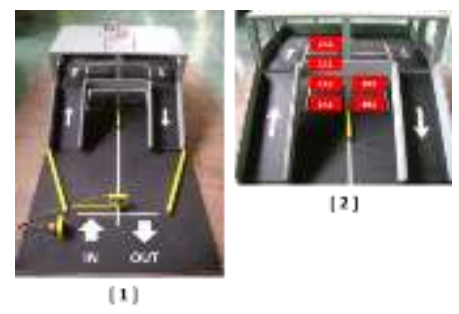

Gambar 3. Prototype Area Parkir Mobil (Trikrisna dkk., 2013)

Program yang dipergunakan yang digunakan untuk membuat tampilan display lokasi pada layar monitor adalah Program Visual Basic 2008. Tampilan sistem dan prototype gedung parkir dapat dilihat pada Gambar 4 dan Gambar 5 (Trikrisna dkk, 2013).

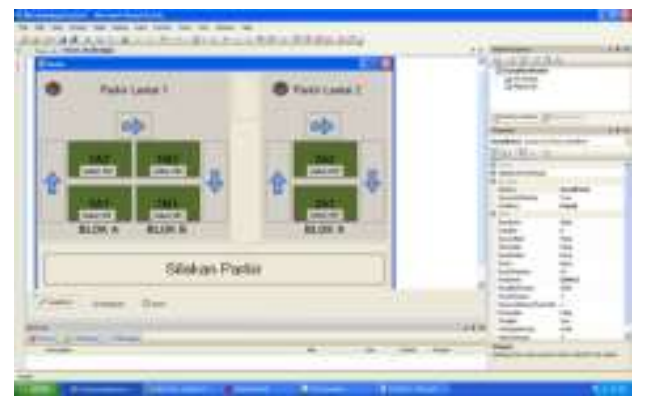

Gambar 4 Tampilan Sistem Informasi Parkir

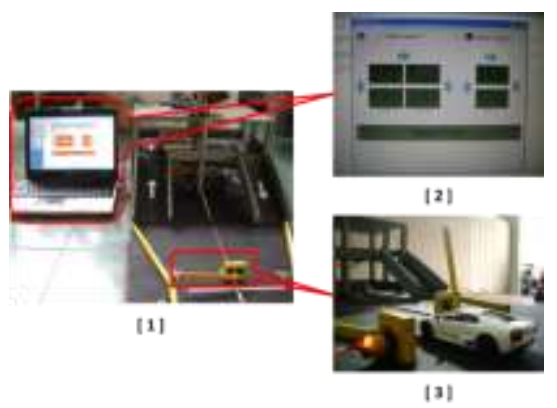

Gambar 5. Prototype Sistem berupa Display Lokasi Parkir dan Parking Gate Portal

Uji coba alat menggunakan 7 buah mobil, 6 mobil satu per satu dimasukan dalam setiap ruangan parkir yang tersedia (Gambar 6a-f), dan 1 mobil tetap berada diluar dan tidak akan bisa masuk area parkir apabila parkir sudah penuh (Gambar 7) (Trikrisna dkk, 2013).

Berdasarkan hasil perancangan prototype, pemodelan sistem informasi perparkiran gedung bertingkat dapat beroperasi dan memberikan informasi lokasi ruangan parkir yang kosong maupun yang terisi secara otomatis. Informasi yang ditampilkan pada display berupa kotak berwarna serta tulisan. Warna kotak "hijau" menunjukkan kondisi lokasi tempat parkir kosong serta tulisan "silahkan parkir", sedangkan jika kotak berwarna "merah" menunjukan 
lokasi yang sudah terisi. Jika semua kotak berwarna "merah", maka informasi tulisan adalah "parkir penuh" dan portal tidak akan membuka.

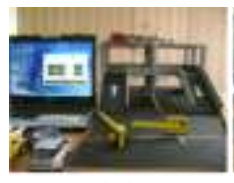

[1]

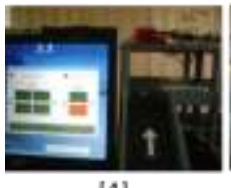

[4]

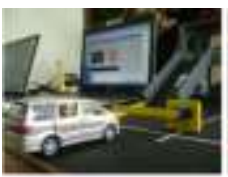

[1]

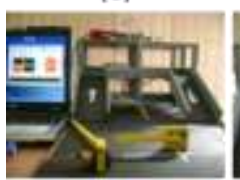

[4]
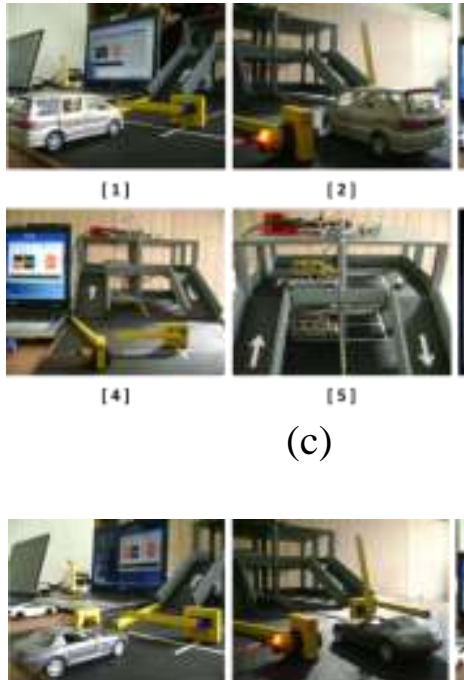

(1)

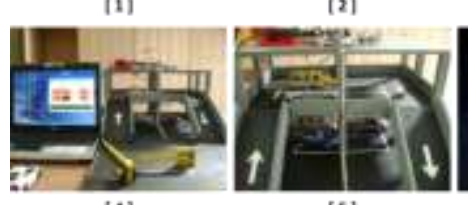

[4]
(2)

[5]

(c)

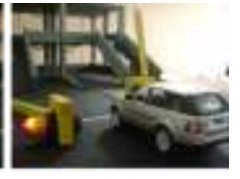

[3]

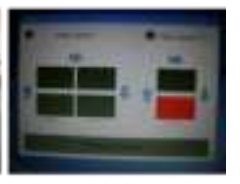

[6]

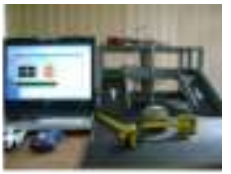

[3]

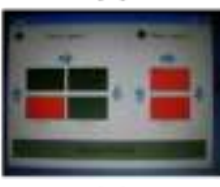

[6]

(e)

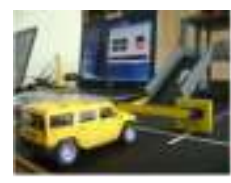

(1)

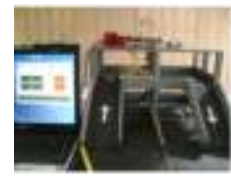

[4]

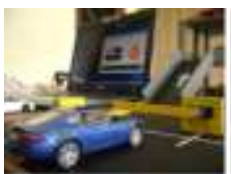

[1]

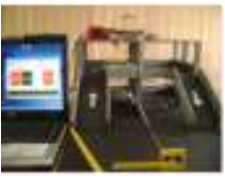

[4]

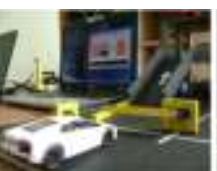

[1]

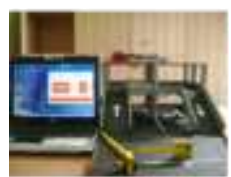

[4]

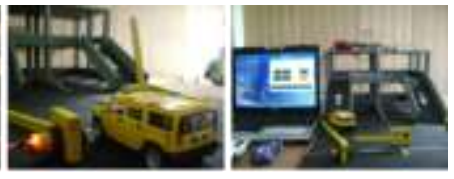

[2]

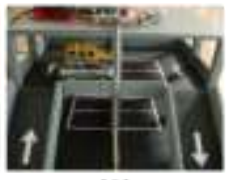

[S]

(b)

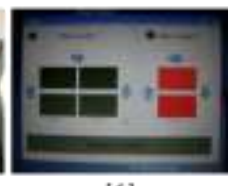

[6]

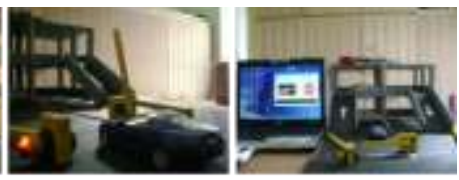

[2]

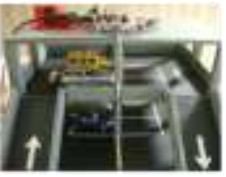

[5]

(d)

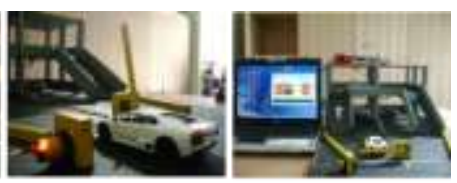

(2)

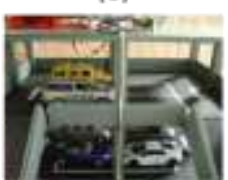

[5]

(f)

Gambar 6. Uji Coba Mobil Pertama Masuk Area Parkir dan Hasil Tampilan Display
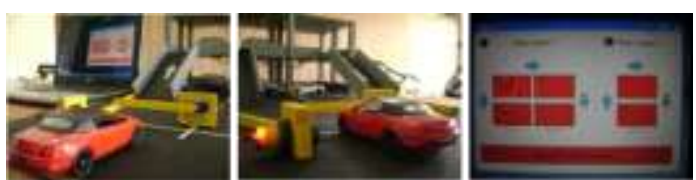

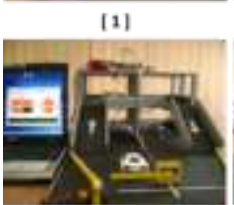

[4]

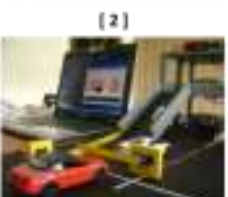

[5]

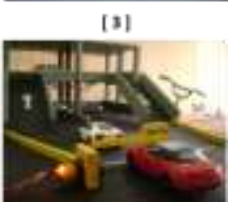

[6]

Gambar 7. Uji Coba Mobil Ketujuh dan Tidak Dapat Memarkir Pada Area Parkir 
Penggunaan warna dan tulisan pada sistem informasi diharapkan pengemudi mampu menerima informasi dengan cepat. Kemampuan mata untuk melihat obyek dipengaruhi oleh ukuran obyek, derajat kontras antara obyek dan sekelilingnya, luminensi (brightness), lamanya melihat, serta warna dan tekstur yang memberikan efek psikologis pada manusia. Mata diharapkan memperoleh cahaya yang cukup, pemandangan yang menyenangkan, menenangkan pikiran, tidak silau, dan nyaman. Esensi dasar dari evaluasi ergonomi dalam proses perancangan adalah sedini mungkin mencoba memikirkan kepentingan manusia agar bisa terakomodasi dalam setiap kreativitas dan inovasi sebuah 'man made object' (Wignjosoebroto, 2000). Fokus perhatian dari sebuah kajian ergonomis akan mengarah ke upaya pencapaian sebuah perancanganan desain suatu produk yang memenuhi persyaratan 'fitting the task to the man' (Granjean, 2000), sehingga setiap rancangan harus selalu memikirkan kepentingan manusia yakni perihal keselamatan, kesehatan, keamanan maupun kenyamanan.

Dalam model sistem interaksi manusia mesin, display memberikan informasi mengenai perkembangan kegiatan/proses yang berlangsung, pengemudi kemudian menyerap informasi ini secara visual menjadi persepsi dan mencoba menginterpretasikannya secara seksama. Berdasarkan interpretasi yang dilakukan serta pengetahuan yang sebelumnya sudah dimiliki maka pengemudi yaitu manusia kemudian membuat keputusan. Hal ini membantu pengemudi dalam menentukan langkah selanjutnya dengan lebih efektif dan efisien, baik dalam waktu serta energi yang dihabiskan.

\section{SIMPULAN}

Pemodelan sistem informasi perparkiran merupakan model sistem interaksi manusia mesin yang mampu membantu manusia khususnya pengemudi dalam mengambil keputusan terhadap kondisi parkir dengan lebih efektif dan efisien. Pemanfaatan sistem informasi perparkiran menggunakan display yang ergonomis sehingga mudah diiunterpretasikan dan mempercepat waktu parker.

\section{DAFTAR PUSTAKA}

Granjean, E. 2000. Fitting the Task to the Man. London: Taylor and Francis.

Pambudi, S. A. 2007. "Rancang Bangun Kendali Sistem Parkir Otomatis Menggunakan Sensor LDR Berbasis Mikrokontroler AT89S51" (tugas akhir). Program Studi Diploma III Instrumentasi Dan Elektronika, Fakultas Matematika Dan Ilmu Pengetahuan Alam. Semarang: Universitas Diponegoro.

Purwanto, D. 2011. "Perancangan Alat Simulasi Garasi Parkir Mobil Otomatis Berbasiskan Mikrokontroler"(naskah publikasi). Yogyakarta: Sekolah Tinggi Manajemen Informatika Dan Komputer Amikom.

Setiawan, D. 2007. Sistem Pengelolaan Parkir Dengan Fasitas Penentuan Lokasi Parkir Terdekat Dengan Pintu Keluar Masuk. Prosiding Seminar Nasional Sistem dan Informatika. Bandung.

Trikrisna, A.B., Swamardika, I.B.A., Wijaya, I W.A. 2013. Desain Sistem Kontrol Parkir Mobil Berbasis Mikrokontroler ATmega 16 Dilengkapi Display Lokasi. E-Journal SPEKTRUM, Vol 5(6).

Wardani, L. K. 2003. Evaluasi Ergonomi Dalam Perancangan Desain. Jurnal Dimensi Interior, Vol. 1(1)61-73.

Winarsih, I. dan Mahendra, R. 2009. Sistem Parkir Otomatis Menggunakan RFID Berbasiskan Mikrokontroler AT 89S51. Jurnal JETri, Vol. 8(2):21 - 36. 
Winjosoebroto, S. 2000. Evaluasi Ergonomi dalam Proses Perancangan Produk. Prosiding. Seminar Nasional Ergonomi. Surabaya. 